\title{
Effects of Soil Acidity Factors on Yields and Foliar Composition of Two Rice Varieties with Supplementary Overhead Irrigation ${ }^{1,2}$
}

\author{
Fernando Abruña and Edmundo Rivera ${ }^{3}$
}

\begin{abstract}
Rice varieties IR8 and Chontalpa 16 growing in two Ultisols with periodic overhead irrigation were quite tolerant to acidity producing around $80 \%$ of maximum yield at $\mathrm{pH} 4.8$ and $30 \%$ Al saturation of the soils cation exchange capacity, a level common in Ultisols. However, maximum yields were obtained at pH 5.5 when no exchangeable Al was present in the soil. The Ca content of the leaves of both rice varieties decreased with decreasing $\mathrm{pH}$ and increasing Al saturation of the soils exchange capacity. Soil acidity factors in an Oxisol did not affect yields of the IR8 variety, even at $\mathrm{pH} 4.5$.
\end{abstract}

\section{INTRODUCTION}

Rice, the most important cereal crop of the tropics, is the major source of carbohydrates for more than 1.5 billion people (6). It is grown under widely different systems: flooded lowlands; rainfed lowland paddies; upland, rainfed; deep water (floating); and rainfed-sprinkle irrigation (3). The first system, flooded lowlands, is the most efficient one and it depends heavily on specialized equipment. It is used mainly in the United States, Australia and some areas of Europe and Latin America. The second system, rainfed lowland paddies, is probably the most widely used and accounts for about $65 \%$ of the rice produced in the tropics (3). About $25 \%$ of the rice produced in tropical countries is grown as upland, rainfed rice; and $9 \%$ is grown in deep water, floating rice $(4,10)$. The use of overhead irrigation to supplement rainfall is being investigated in Arkansas and other rice producing areas of the United States as an alternative when water is scarce or expensive or the soil is not suited to flooding (5).

Soil acidity, and consequently $\mathrm{Al}, \mathrm{Mn}$, and possibly $\mathrm{Fe}$ toxicities, are not a problem under flooding, which raises the $\mathrm{pH}$ of mineral soils to near neutrality (10). On lowland soils that are high in sulfides, however, rice may be seriously affected by $\mathrm{Al}, \mathrm{Mn}$ and Fe toxicities $(1,8,11,13)$. On the other hand, upland rainfed rice may respond to liming because much of it is grown on acid Ultisols and Oxisols. Only limited information is available on the response of upland rice to liming. Spain et al. (12), when working with acid Oxisols from Colombia, found that the tall

${ }^{1}$ Manuscript submitted to Editorial Board November 10, 1983

${ }^{2}$ Research conducted cooperatively between the Agricultural Research Service, USDA, and the College of Agricultural Sciences, Mayagüez Campus, University of Puerto Rico.

${ }^{3}$ Soil Scientist and Horticulturist, Agricultural Research Service, USDA, respectively. 
varieties Blue Bonnet 50 and Monolaya responded to applications of 0.4 $\mathrm{t}$ of $\mathrm{CaCO}_{3} / \mathrm{ha}$, but responded no further to higher levels. However, the semidwarf types Cica-4 and IR8 responded strongly to applications of 4 t of $\mathrm{CaCO}_{3} /$ ha. Ponamperuma (9), reported striking increases in yields in Oxisols from Ceylon, as a result of applying $13 \mathrm{t}$ of slaked lime per hectare.

The studies reported herein were conducted to determine the effect of soil acidity factors on yields and foliar composition of rice grown with overhead irrigation on two Ultisols and one Oxisol.

\section{MATERIALS AND METHODS}

Field experiments were conducted in 30 plots on Corozal clay soil (Aquic Tropudults) in 30 plots of Corozal clay subsoil, and in 40 plots of Coto sandy clay (Tropeptic Haplorthox). Plots were $4 \mathrm{~m}^{2}$ arranged in a completely randomized design, and differing in soil acidity as a result of varying rates of calcitic limestone applied over previous years. Each plot was surrounded by $15-\mathrm{cm}$ deep ditches to prevent runoff from one plot onto another.

In December 1973 all plots were seeded to IR8, a long grain variety, at the rate of $80 \mathrm{~kg} / \mathrm{ha}$ planted in rows $30 \mathrm{~cm}$ apart. In June 1974 all plots in Corozal soil and subsoil were seeded to Chontalpa 16, a medium grain variety, at the rate of $90 \mathrm{~kg} / \mathrm{ha}$, and planted in rows $20 \mathrm{~cm}$ apart. Both of these varieties are often grown as upland rice in the Orient and in Mexico.

Before the rice was planted, $50 \mathrm{~kg}$ of $\mathrm{N}, 40 \mathrm{~kg}$ of $\mathrm{P}_{2} \mathrm{O}_{5}$ and $50 \mathrm{~kg}$ of $\mathrm{K}_{2} \mathrm{O} /$ ha were incorporated into the upper $10 \mathrm{~cm}$ of soil. An additional 50 $\mathrm{kg}$ of N/ha was applied as a sidedressing 45 days after planting. The IR 8 variety received a third application of $30 \mathrm{~kg} / \mathrm{ha} 18$ days later.

All plots were irrigated by sprinklers to supplement rainfall and to maintain soil moisture near field capacity. Weeds were controlled by applying Propanil ${ }^{4}$ at the rate of $12 \mathrm{~L} / \mathrm{ha}, 21$ and 42 days after planting. Cutworms were controlled by spraying once with Diazinon AG 500 at the rate of $2 \mathrm{~L} / \mathrm{ha}$. Sucking insects were controlled by spraying with Malathion at the rate of $2 \mathrm{~L} / \mathrm{ha}$ at heading and early milk stages. Diseases were controlled with two applications of Benomyl at the rate of $.5 \mathrm{~kg} / \mathrm{ha}$ applied at the internode elongation and blooming stages.

Yields of rough rice were determined by harvesting a $3-\mathrm{m}^{2}$ section in

${ }^{4}$ Trade names in this publication are used only to provide specific information. Mention of a trade name does not constitute a warranty of equipment or materials by the Agricultural Experiment Station of the University of Puerto Rico or Agricultural Research Service, USDA, nor is this mention a statement of preference over other equipment or materials. 
the center of each plot when grain moisture was $22 \%$, and then drying to $12 \%$.

The second leaves of plants in the center of each plot were sampled just before blooming, dried at $70^{\circ} \mathrm{C}$, and analyzed for $\mathrm{N}$ by the Kjeldahl method, for $\mathrm{P}$ by colorimetry, as a molibdate; for $\mathrm{K}$ by flame photometry, for $\mathrm{Ca}$ and $\mathrm{Mg}$ by the Versenate method (2), and for Mn by colorimetry as $\mathrm{KMnO}_{4}$.

Soil samples were taken from each plot about 20 days after planting. Ten borings were taken at 0 - to $15-\mathrm{cm}$ depth, air dried, and passed through a 20-mesh screen. Exchangeable $\mathrm{Ca}, \mathrm{Mg}, \mathrm{K}$, and $\mathrm{Mn}$ were extracted with neutral $\mathrm{N} \mathrm{NH}_{4} \mathrm{OAc}$. Calcium and $\mathrm{Mg}$ were determined by the Versenate titration method (2), $\mathrm{K}$ by flame photometry, and Mn by colorimetry as $\mathrm{KMnO}_{4}$. Exchangeable $\mathrm{Al}$ was extracted with $\mathrm{N} \mathrm{KCl}$ and determined by the McLean (7) double titration method. Percent Al saturation of the soil was calculated on the basis that exchangeable $\mathrm{Ca}$ $+\mathrm{Mg}+\mathrm{K}+\mathrm{Al}+\mathrm{H}$ was the effective cation exchange capacity (CEC) of the soil. Using a 1:1.5 soil-to-water ratio, we measured soil reaction with a glass electrode $\mathrm{pH}$ meter.

Yield data were correlated with soil-acidity factors through regression analyses.

\section{RESULTS AND DISCUSSION}

\section{VARIETY IR8}

Variety IR8 produced low yields but appeared to tolerate soil acidity quite well on both Corozal soils. On the Corozal clay soil, yield was maximum when $\mathrm{pH}$ was 5.8 and no exchangeable $\mathrm{Al}$ was present in the soil (table 1), but $85 \%$ of maximum yield was obtained at a soil $\mathrm{pH}$ of 4.6 and $\mathrm{Al}$ saturation of $38 \%$. Yields decreased to only $765 \mathrm{~kg} / \mathrm{ha}$ when soil $\mathrm{pH}$ was 4.2 and $\mathrm{Al}$ saturation was $68 \%$.

Phosphorus and $\mathrm{Ca}$ were the only constituents of the rice leaves that were appreciably affected by soil acidity, decreasing from $.21 \%$ and $.42 \%$ to $.16 \%$ and $.25 \%$, respectively, when $\mathrm{pH}$ of the Corozal soil dropped from 5.8 to 4.2 (table 1 ).

This variety yielded similarly on both the Corozal clay soil and subsoil, but the response to soil acidity was more striking in the subsoil than in the Corozal soil (table 1). At the $40 \% \mathrm{Al}$ saturation, yield in the Corozal subsoil was only $70 \%$ of the maximum as compared to $85 \%$ at $38 \% \mathrm{Al}$ saturation on the Corozal clay soil. At the extreme acidity level, this rice variety produced only $28 \%$ of the maximum yield on the Corozal subsoil compared to $43 \%$ on the Corozal clay soil.

The chemical composition of the rice leaves (table 1) was not appre- 
ciably affected by soil acidity levels, except for the Ca content that decreased from $.48 \%$ when the $\mathrm{pH}$ of Corozal subsoil was 5.7 and with no exchangeable $\mathrm{Al}$ to $.28 \%$ at the highest level of soil acidity $(\mathrm{pH} 4.2$ and $64 \% \mathrm{Al}$ saturation).

Regression analyses of the data (table 2) indicated that all of the soil acidity factors in the Corozal clay soil and subsoil were significantly correlated with grain yields. Grain yield was best correlated with $\mathrm{Ca}$ saturation percentage of the Corozal soil and with the $\mathrm{pH}$ of the Corozal subsoil.

TABLE 1. - The effect of soil acidity factors on yield and foliar composition of IR8 rice variety grown on two Ultisols and one Oxisol. All values are averages of at least four plots for Corozal soils and six for Coto soil

\begin{tabular}{|c|c|c|c|c|c|c|c|c|c|c|c|}
\hline \multicolumn{4}{|c|}{ Soil acidity factors } & \multicolumn{2}{|c|}{ Yield } & \multicolumn{6}{|c|}{ Foliar composition } \\
\hline $\mathrm{pH}$ & $\begin{array}{c}\text { Al } \\
\text { sat. }\end{array}$ & $\begin{array}{l}\mathrm{Ca} \\
\text { sat. }\end{array}$ & $\mathrm{A} / \mathrm{Ca}$ & Actual & Relative & $\mathrm{N}$ & $\mathrm{P}$ & $\mathbf{K}$ & $\mathrm{Ca}$ & $\mathrm{Mg}$ & $\mathrm{Mn}$ \\
\hline & $\%$ & & Ratio & $\mathrm{kg} / \mathrm{ha}$ & $\%$ & & & & & & $p / m$ \\
\hline \multicolumn{12}{|c|}{ Corozal clay soil } \\
\hline 5.8 & 0 & 84 & 0 & 1766 & 100 & 2.24 & .21 & 2.42 & .42 & .29 & 590 \\
\hline 5.1 & 7 & 78 & .09 & 1750 & 99 & 2.21 & .20 & 2.25 & .41 & .28 & 660 \\
\hline 4.7 & 24 & 60 & .40 & 1542 & 87 & 2.21 & .18 & 2.47 & .42 & .23 & 680 \\
\hline 4.6 & 38 & 40 & .96 & 1504 & 85 & 2.40 & .17 & 2.33 & .37 & .27 & 700 \\
\hline 4.5 & 50 & 37 & 1.36 & 1118 & 63 & 2.49 & .16 & 2.39 & .37 & .29 & 600 \\
\hline 4.2 & 68 & 24 & 2.83 & 765 & 43 & 2.05 & .16 & 2.38 & .25 & .28 & 520 \\
\hline \multicolumn{12}{|c|}{ Corozal clay subsoil } \\
\hline 5.7 & 0 & 82 & 0 & 2260 & 100 & 2.46 & .17 & 2.37 & .48 & .26 & 600 \\
\hline 5.0 & 8 & 72 & .11 & 1796 & 80 & 2.55 & .15 & 2.31 & .42 & .31 & 500 \\
\hline 4.7 & 25 & 49 & .52 & 1723 & 76 & 2.53 & .15 & 2.27 & .39 & .27 & 536 \\
\hline 4.4 & 40 & 46 & .87 & 1572 & 70 & 2.51 & .14 & 2.30 & .38 & .27 & 540 \\
\hline 4.3 & 52 & 27 & 1.92 & 897 & 40 & 2.33 & .14 & 2.28 & .28 & .28 & 500 \\
\hline 4.2 & 64 & 25 & 2.58 & 629 & 28 & 2.48 & .14 & 2.42 & .28 & .26 & 560 \\
\hline \multicolumn{12}{|c|}{ Coto sandy clay } \\
\hline 5.6 & 0 & 86 & 0 & 2772 & 82 & 3.02 & .16 & 2.51 & .48 & .30 & 1000 \\
\hline 5.0 & 6 & 80 & .08 & 3172 & 94 & 3.15 & .16 & 2.51 & .49 & .31 & 980 \\
\hline 4.7 & 12 & 73 & .16 & 3370 & 100 & 3.11 & .16 & 2.57 & .49 & .33 & 900 \\
\hline 4.5 & 36 & 44 & .82 & 3339 & 99 & 3.08 & .16 & 2.52 & .41 & .30 & 968 \\
\hline 4.5 & 41 & 40 & 1.03 & 3175 & 94 & 3.02 & .16 & 2.47 & .47 & .31 & 960 \\
\hline
\end{tabular}

As indicated in table 1, variety IR8 produced higher yields on the Coto sandy clay soil than on the Corozal soils; soil acidity factors had no effect on grain yields or foliar composition of the rice grown in Coto sandy clay. The lack of response to acidity in this soil at the $\mathrm{Al}$ saturation values of the other two soils indicated either that the Al forms in the Coto soil may be less active than those in the Ultisols or that the high Mn content of this soil may inhibit $\mathrm{Al}$ activity to some extent. 
TABLE 2.-Regression coefficients and $F$ values for equations between soil acidity factors and yields of two rice varieties grown on two Ultisols and one Oxisol

\begin{tabular}{|c|c|c|c|c|}
\hline \multicolumn{3}{|c|}{ IR8 Variety } & \multirow{2}{*}{\multicolumn{2}{|c|}{$\begin{array}{c}\text { Chontalpa variety } \\
\text { Yields of rough rice } \\
\mathrm{kg} / \mathrm{ha}\end{array}$}} \\
\hline \multirow{2}{*}{$\begin{array}{l}\text { Soil acidity } \\
\text { factor }\end{array}$} & \multicolumn{2}{|c|}{$\begin{array}{l}\text { Yields of rough rice } \\
\mathrm{kg} / \mathrm{ha}\end{array}$} & & \\
\hline & $\mathrm{R}$ & $\mathrm{F}$ & $\mathrm{R}$ & $\mathrm{F}$ \\
\hline \multicolumn{5}{|c|}{ Corozal clay soil } \\
\hline $\mathrm{pH}$ & $.49^{* 1}$ & $4.37^{*}$ & $.60^{* * 2}$ & $14.80^{* *}$ \\
\hline Al sat. $\%$ & $.56^{* *}$ & $6.32^{* *}$ & $.62^{* *}$ & $13.32^{* *}$ \\
\hline Ca sat. $\%$ & $.62^{* * *}$ & $8.54^{* *}$ & $.61^{* *}$ & $16.18^{* *}$ \\
\hline Exch. Al & $.52^{* * *}$ & $10.65^{* *}$ & $.57^{* *}$ & $13.24^{* *}$ \\
\hline \multicolumn{5}{|l|}{$\overline{\text { Exch. Ca }}$} \\
\hline \multicolumn{5}{|c|}{ Corozal clay subsoil } \\
\hline $\mathrm{pH}$ & $.67^{* *}$ & $22.86^{* *}$ & $.68^{* *}$ & $22.72^{* * *}$ \\
\hline Al sat. \% & $.64^{* *}$ & $19.71^{* *}$ & $.74^{* *}$ & $33.51^{* * *}$ \\
\hline Ca sat. \% & $.59^{* *}$ & $13.56^{* *}$ & $.70^{* *}$ & $27.10^{* * *}$ \\
\hline Exch. Al & $.62^{* *}$ & $17.58^{* *}$ & $.74^{* *}$ & $15.88^{* *}$ \\
\hline Exch. Ca & & & & \\
\hline
\end{tabular}

${ }^{1}$ Significant at the $5 \%$ level.

${ }^{2}$ Significant at the $1 \%$ level.

TABLE 3.-Effect of soil acidity factors on yields of rough rice and foliar composition of the Chontalpa 16 variety of rice grown on two Ultisols. All values are averages of at least four plots

\begin{tabular}{|c|c|c|c|c|c|c|c|c|c|c|c|}
\hline \multicolumn{4}{|c|}{ Soil acidity factors } & \multicolumn{2}{|c|}{ Yield } & \multicolumn{6}{|c|}{ Foliar composition } \\
\hline $\mathrm{pH}$ & $\begin{array}{l}\mathrm{Al} \\
\text { sat. }\end{array}$ & $\begin{array}{l}\mathrm{Ca} \\
\text { sat. }\end{array}$ & $\mathrm{Al} / \mathrm{Ca}$ & Actual & Relative & $\mathrm{N}$ & $\mathrm{P}$ & $\mathrm{K}$ & $\mathrm{Ca}$ & $\mathrm{Mg}$ & $\mathrm{Mn}$ \\
\hline & $\%$ & $\%$ & Ratio & $k g / h a$ & $\%$ & $\%$ & $\%$ & $\%$ & $\%$ & $\%$ & $\%$ \\
\hline \multicolumn{12}{|c|}{ Corozal clay soil } \\
\hline 5.7 & 0 & 91 & 0 & 3375 & 100 & 3.34 & .19 & 1.64 & .68 & .22 & 275 \\
\hline 5.1 & 9 & 76 & .13 & 2787 & 83 & 3.32 & .17 & 1.60 & .66 & .29 & 335 \\
\hline 4.9 & 24 & 58 & .43 & 2587 & 77 & 3.25 & .20 & 1.75 & .60 & .25 & 466 \\
\hline 4.7 & 38 & 48 & .81 & 2113 & 63 & 3.42 & .19 & 1.98 & .55 & .24 & 550 \\
\hline 4.4 & 57 & 31 & 1.87 & 1725 & 51 & 3.39 & .18 & 1.87 & .46 & .23 & 348 \\
\hline 4.2 & 63 & 22 & 2.86 & 1579 & 47 & 3.48 & .19 & 1.90 & .42 & .19 & 365 \\
\hline \multicolumn{12}{|c|}{ Corozal clay subsoil } \\
\hline 5.8 & 0 & 91 & 0 & 3340 & 100 & 3.30 & .19 & 1.65 & .65 & .24 & 273 \\
\hline 5.0 & 9 & 83 & .11 & 2960 & 89 & 3.37 & .21 & 1.77 & .67 & .23 & 373 \\
\hline 4.8 & 23 & 60 & .38 & 2355 & 71 & 3.30 & .21 & 1.85 & .63 & .19 & 690 \\
\hline 4.6 & 38 & 45 & .86 & 2206 & 66 & 3.25 & .20 & 1.82 & .61 & .20 & 765 \\
\hline 4.4 & 52 & 30 & 1.75 & 2138 & 64 & 3.14 & .21 & 1.83 & .47 & .23 & 443 \\
\hline 4.2 & 66 & 23 & 2.87 & 1706 & 51 & 3.26 & .21 & 2.08 & .46 & .22 & 382 \\
\hline
\end{tabular}

\section{CHONTALPA 16 VARIETY}

The Chontalpa 16 variety was grown on the Corozal soils only. This variety produced higher yields on both of these soils (table 3) than did the IR8 variety (table 1), but its response to soil acidity was more marked 
than that of variety IR8. More than $3,300 \mathrm{~kg}$ of rough rice/ha were produced on both soils at about $\mathrm{pH} 5.8$ with no exchangeable Al present, compared to 1766 and $2260 \mathrm{~kg} / \mathrm{ha}$ produced by variety IR 8 at similar $\mathrm{pH}$ levels on Corozal soil and subsoil, respectively (tables 1 and 3). Yields were lowest when soil pH dropped to 4.2 and Al saturation of the Corozal soil was $63 \%$ and that of the Corozal subsoil was $66 \%$.

On the Corozal clay soil, Ca content of the leaves decreased from .68\% at pH 5.7 with no exchangeable $\mathrm{Al}$ present in the soil to $.42 \%$ at $\mathrm{pH} 4.2$.

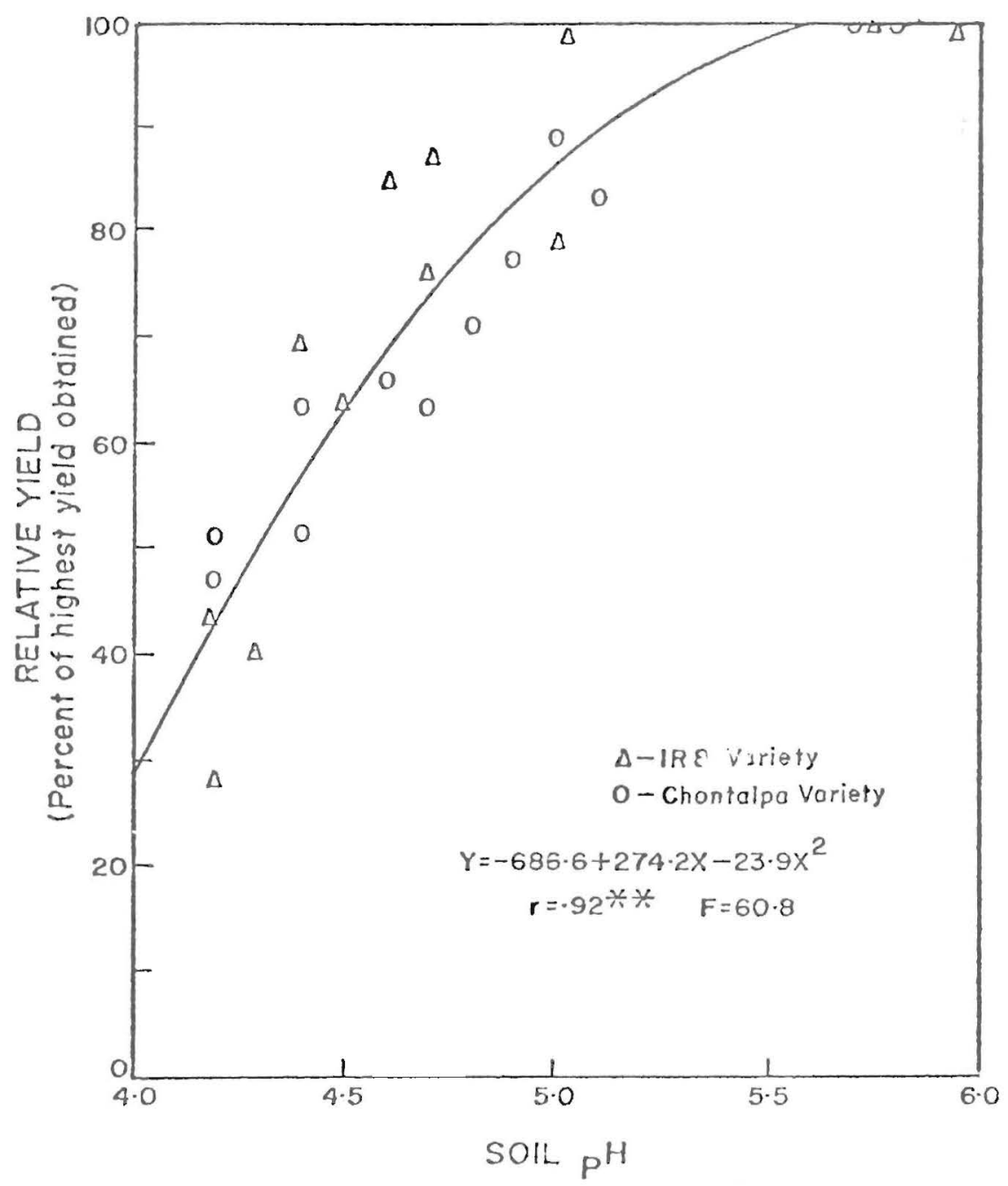

FIG. 1.-Relationship between the $\mathrm{pH}$ of two Ultisols and the relative yield of two rice varieties. 


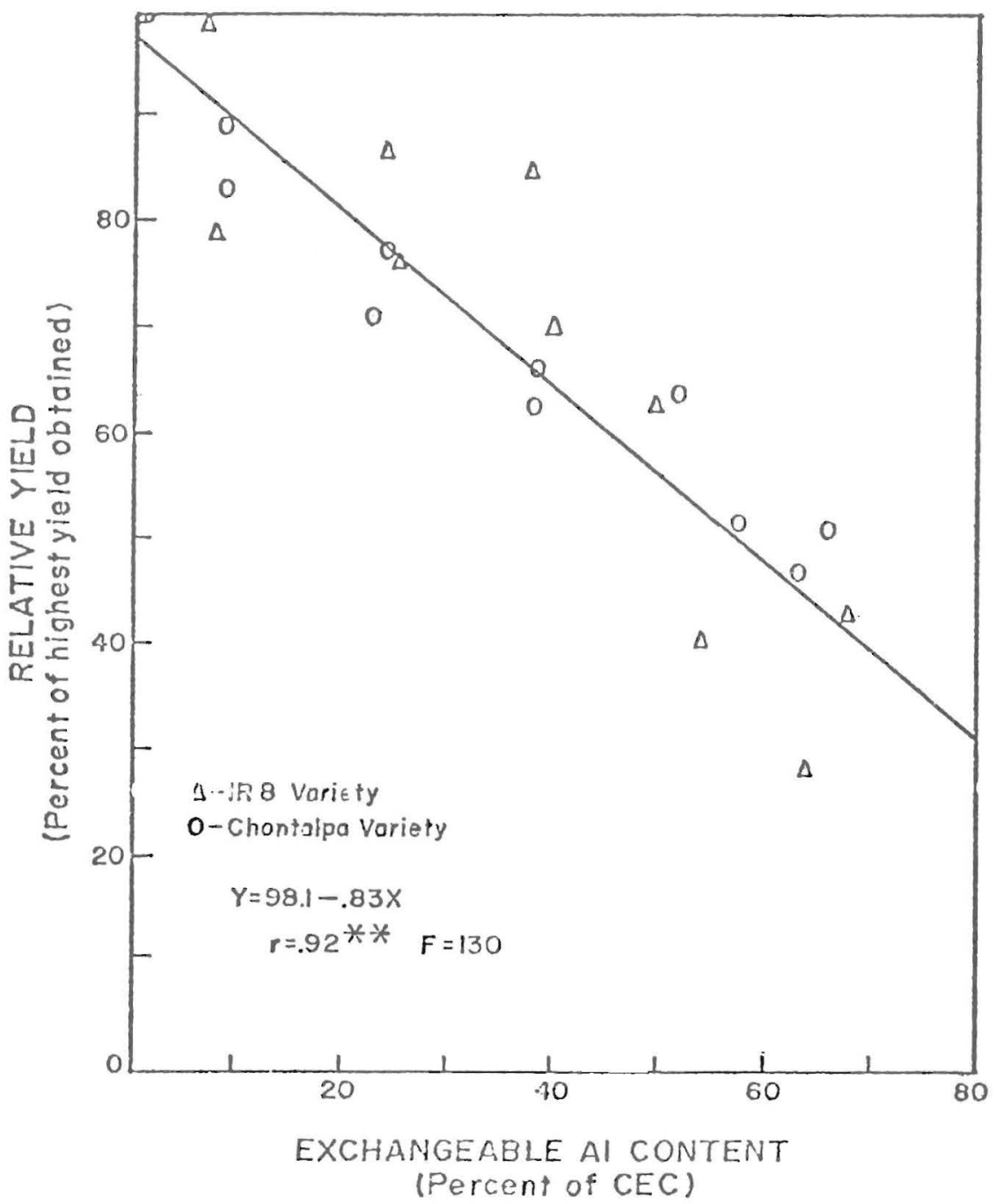

FIG. 2.-Relationship between the exchangeable aluminum content of two Ultisols and the relative yield of two rice varieties.

The $\mathrm{K}$ content tended to increase with increasing acidity, but the other constituents were not affected by soil acidity. Results were similar in the Corozal subsoil.

\section{BOTH VARIETIES}

Regression analyses of the data (table 2) indicated that grain yields were significantly correlated with soil-acidity factors. With the Corozal clay soil, the percentage of $\mathrm{Al}$ saturation of the soil explained $38 \%$ of the 
variations in grain yields; and with the Corozal subsoil, it explained $55 \%$ of the variation.

Regression analyses of the combined data for the Ultisols revealed that the two varieties were similarly tolerant to soil-acidity factors.

When the relative yields of both varieties on both Ultisols were combined, the regression analyses indicated that yields were maximum when $\mathrm{pH}$ was about 5.5 (fig. 1) and no exchangeable $\mathrm{Al}$ was present in the soil (fig. 2). As indicated in figure 2, about $65 \%$ of maximum yield

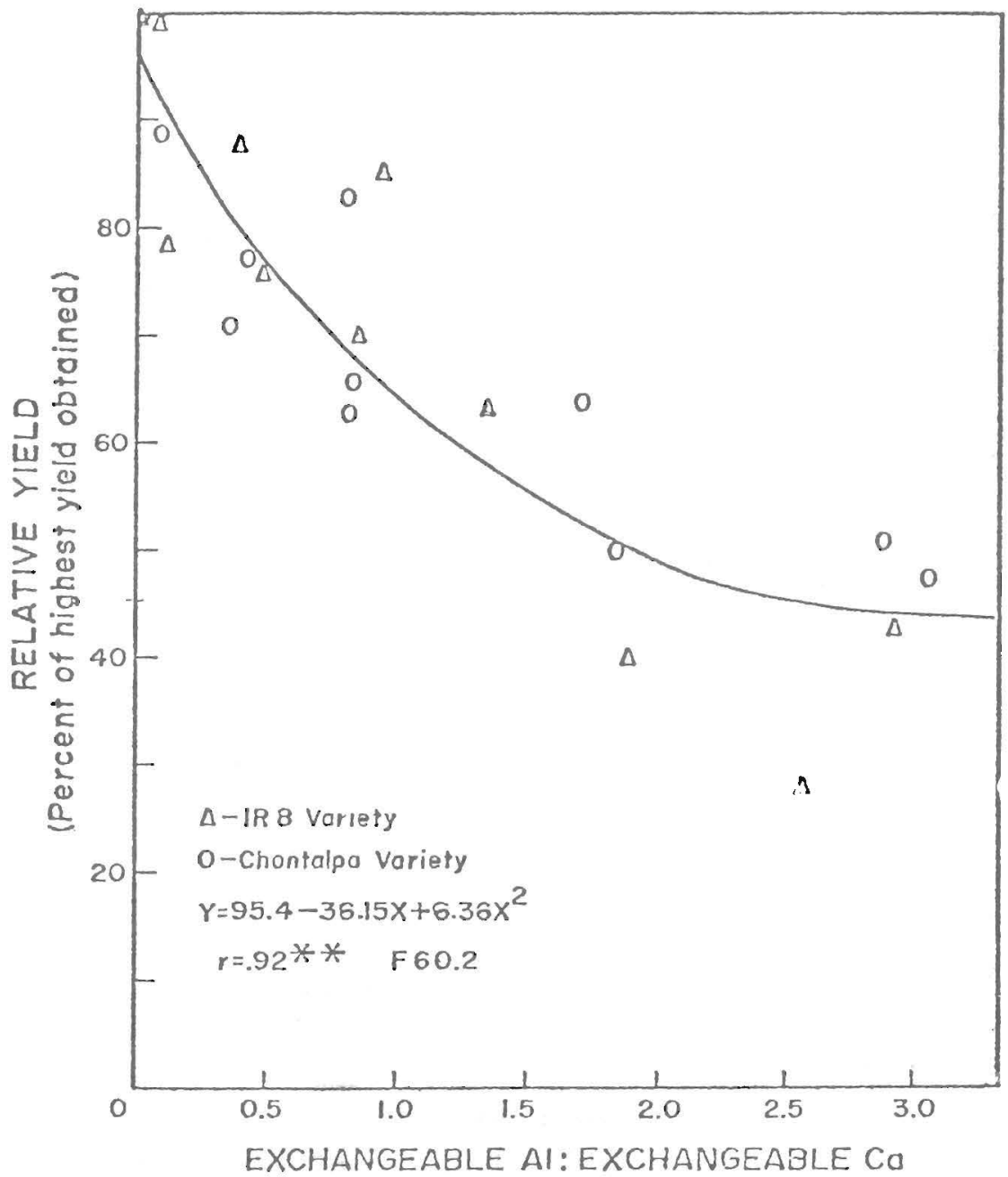

FIG. 3.-Relationship between exchangeable $\mathrm{Al} / \mathrm{Ca}$ of two Ultisols and the relative yield of two rice varieties. 
would be expected when $\mathrm{Al}$ saturation of the soil is $40 \%$, a level very common in Ultisols. About $80 \%$ of maximum yield is to be expected when the $\mathrm{Al}$ :Ca ratio is less than 0.5 (fig. 3 ), whereas only $45 \%$ of maximum yields is produced with ratios higher than 2 .

We concluded that rainfed-rice of both the IR8 and Chontalpa 16 varieties grown with supplementary irrigation on Ultisols respond to liming up to $\mathrm{pH} 5.5$, but about $80 \%$ of maximum production can be obtained at $\mathrm{pH}$ values of about 4.8. Al saturation of the soil seems to be the soil acidity factor mainly responsible for depressing the yields at low $\mathrm{pH}$. values in Ultisols. The Chontalpa 16 variety produced higher yields than the IR8 variety.

\section{RESUMEN}

Se estudiaron los efectos de los factores de acidez sobre la producción y composición foliar de dos variedades de arroz en dos Ultisol y un Oxisol regadas por aspersión. Ambas variedades mostraron ser tolerantes a los factores de acidez, ya que produjeron alrededor del $80 \%$ del rendimiento máximo cuando el suelo tenía un pH de 4.8 y el $30 \%$ del complejo coloidal estaba saturado con Al cambiable. Este nivel de acidez es muy común en los Ultisol de Puerto Rico.

Las producciones más altas se lograron a valores de $\mathrm{pH}$ superiores a 5.5 a los cuales el Al se precipita como $\mathrm{Al}(\mathrm{OH})_{3}$.

El contenido en calcio en las hojas disminuyó cuando el pH de los Ultisol bajó y el contenido en Al cambiable aumentó.

La variedad Chontalpa 16 produjo rendimientos más altos que la IR8 a niveles de acidez comparables en los Ultisol.

Los factores de acidez en el suelo Coto no tuvieron efecto sobre la producción de la variedad IR8.

La falta de respuesta al encalado en el Oxisol a niveles de acidez comparables a los de los Ultisol pudiera deberse a formas menos activas del $\mathrm{Al}^{3+}$ en el suelo Coto o a que el alto contenido en $\mathrm{Mn}$ en este suelo inhiba la actividad del $\mathrm{Al}^{3+}$.

\section{LITERATURE CITED}

1. Cate, R. B. and Sukhai, A. P., 1964. A study of aluminum in rice soils, Soil Sci. 98: 8593.

2. Cheng, K. L. and Bray, R. H., 1951. Determination of calcium and magnesium in soil and plant material, Soil Sci. 72: 449-58.

3. C.I.A.T. 1972. Politicas arroceras en América Latina, Informaciön básica y antecedentes. Centro Internacional de Agricultura Tropical. Cali, Colombia.

4. FAO, 1970. Production Yearbook. Food and Agricultural Organization of the United Nations, Rome.

5. Ferguson, J. A., Gilmour, J. T. and Mermound, D. E., 1980. Rice production using overhead irrigation in Arkansas Proc. 18th Rice Technical Working Group. Texas Agric. Exp. Stn. Texas A and M Univ. College Sta., Texas. 
6. Grist, D. H., 1959. Rice, 3rd ed, Longmans Green and Co. Ltd., London.

7. McLean, E. O., 1965. Aluminum. In C. A. Black et al. (Ed) Methods of soil analyses, part 2. Agronomy 9:994-96. Am. Soc. Agron. Madison, Wis.

8. Moorman, F. R. 1961. Acid sulphate soils of the tropics. In Research on Acid Sulphate Soils and their Amelioration by Liming. Agronomy Library, Ministry of Rural Affairs, Vietnam.

9. Ponamperuma, F. N., 1960. The benefits of liming acid lateritic rice soils of Ceylon. Trans. Inter. Congr. Soil Sci. 7th Congress, Madison 3 (285-92).

10. Sánchez, P. A., 1976. Properties and Management of Soils in the Tropics, John Wiley and Sons, N.Y., p. 436.

11. Simonson, C. H. 1958. Reconnaissance Soil Survey of the Coastal Plains of British Guiana.

12. Spain, J. M., Francis, C. A., Howler, R. H. and Calvo, F., 1972. Differential species and varietal tolerance to soil acidity in tropical crops and pastures. In Soil Management in Tropical America. Univ. Consortium on Soils of the Tropics. N. C. State Univ., Raleigh.

13. Tomlinson, T. E., 1957. Changes in a sulphide-containing mangrove soil on drying and the effect of the suitability of the soil for the growth of rice. Empire J. Exp. Agric. 25: $103-18$. 